\title{
Cathepsin D
}

\author{
CHARACTERISTICS OF IMMUNOINHIBITION \\ AND THE CONFIRMATION OF A ROLE IN CARTILAGE BREAKDOWN
}

\author{
BY J. T. DINGLE, A. J. BARRETT AND P. D. WESTON* \\ Strangeways Research Laboratory, Cambridge CB1 4RN, U.K.
}

(Received 8 January 1971)

\begin{abstract}
1. Antisera were raised against lysosomal cathepsin $D$ of man, chicken and rabbit. 2. The antisera were found to be specific and potent inhibitors of cathepsin $D$ activity. 3. The immunological nature of the inhibition was established. 4. The inhibitory effect was studied by varying $\mathrm{pH}$, antiserum/enzyme ratio, time of incubation, concentration of components and order of mixing, and by using purified antibody and univalent antibody fragments. 5. The specificities of the antisera were examined with respect to other enzymes, isoenzymes of cathepsin $D$ and cathepsin $D$ from different organs. 6. The antisera prevented the action of cathepsin $\mathrm{D}$ on isolated proteoglycans and on cartilage. 7. The antisera produced up to $90 \%$ inhibition of the autolysis of cartilage from chicks and rabbits, indicating that cathepsin $\mathbf{D}$ is the enzyme mainly responsible for the breakdown of proteoglycans in this system.
\end{abstract}

Recent work has suggested that the lysosomal system plays a key role in the catabolism of the proteoglycans of cartilage (for reviews see Barrett, 1968; Dingle, 1969), and there is strong, though circumstantial, evidence that this process is mediated primarily by lysosomal cathepsin D. Other workers have proposed the involvement of hyaluronidase (Bollet, Handy \& Sturgill, 1963; Weissman \& Spilberg, 1968), cathepsin B (Ali, 1964; Ali, Evans, Stainthorpe \& Lack, 1967) and $\beta$ xylosidase (Fisher, Higham, Kent \& Pritchard, 1966; Fisher, Whitehouse \& Kent, 1967), whereas Woessner (1967) has added further weight to the indirect evidence in favour of the importance of cathepsin $D$. If the hypothesis that cathepsin $D$ is the enzyme primarily responsible for the breakdown of cartilage matrix proves to be correct, it has important implications in the pathology of connective-tissue disease, particularly arthritis (Dingle, 1962, 1968; Hamerman \& Barland, 1966; PageThomas, 1969; Weissman \& Spilberg, 1968). One way in which this hypothesis could be tested would be to inhibit the enzyme in a biological test system. Since no suitable specific chemical inhibitor is known, we examined the possibility that antibodies to cathepsin D could be used for this purpose. To this end, we have now raised specific antisera against the purified enzyme from liver of chicken

* Present address: Institut de Recherches Scientifiques sur le Cancer, 16 Avenue Vaillant-Couturier, B.P. no. 8, 94 Villejuif, France.
(Weston, 1969), rabbit and man. The present paper reports the properties of the antisera as specific inhibitors of cathepsin $D$ and defines the role of this enzyme in cartilage autolysis. A preliminary account of part of this work has been published (Barrett, 1969).

\section{MATERIALS}

Bovine serum albumin was Cohn fraction V obtained from Armour Pharmaceutical Co. Ltd., Eastbourne, Sussex, U.K., and chondroitin sulphate (ex shark) was from Koch-Light Laboratories Ltd., Colnbrook, Bucks., U.K. Special Agar-Noble and Freund's adjuvants were products of Difco Laboratories, Detroit, Mich., U.S.A., and twice-crystallized papain and pepsin were bought from Sigma (London) Chemical Co., London S.W.6, U.K. Sephadex G-75 and Sepharose 4B were obtained from Pharmacia (G.B.) Ltd., London W.13, U.K.; DEAEcellulose was Whatman DE-52 from W. and R. Balston Ltd., Maidstone, Kent, U.K. Cartilage protein-polysaccharide from bovine nasal septa was 'light proteinpolysaccharide' preparation PP-L, prepared as described by Gerber, Franklin \& Schubert (1960).

The preparation and assay of cathepsin $D$ and the nomenclature of the isoenzymes are described by Barrett (1970). Two types of cathepsin D preparation were used: (a) mixtures of all isoenzymes, referred to simply as 'cathepsin D', not purified by isoelectric focusing, and having a specific activity of approx. $80 \%$ of the value obtained with more extensively purified preparations; (b) the pure $\beta$ - and $\gamma$-isoenzymes, isolated by isoelectric focusing (Barrett, 1970).

Bioch. 1971, 123 


\section{METHODS}

Raising and testing antisera. All animals were bled before immunization to provide control sera, and pooled normal sheep serum was prepared from the blood of 11 ewes. Control sera and antisera were all stored at $-20^{\circ} \mathrm{C}$ without any preservative. Sheep and rabbit sera were labelled with the animal number (prefixed ' $S$ ' and ' $R$ ' respectively) followed by the bleed number, bleed 0 being that taken before the first injection. Initially, straight precipitin lines (Plate $1 b$ ) were injected as described by Weston (1969); in later work soluble preparations of the enzyme were emulsified with complete Freund's adjuvant $(1: 1, v / v)$ and injected intramuscularly into rabbits and sheep on days 0 and 15. The animals were bled on day 25. The methods used to examine the specificity of the antisera were essentially those of Weston (1969).

The relative concentrations of precipitating antibodies in the antisera were determined by single radial immunodiffusion, essentially as described by Vaerman, LebacqVerheyden, Scolari \& Heremans (1969) with agar or agarose gels containing 2 or 5 units of cathepsin $D / m l$ (Plate 1a).

Preparation of $\mathrm{Ig} G^{*}$ from serum. Sera were dialysed against 20 mM-sodium phosphate buffer, $\mathrm{pH} 8$, and chromatographed on a column of DEAE-cellulose equilibrated with the same buffer. The products were shown by immunoelectrophoresis to be pure IgG2, and IgGl (nomenclature of Feinstein \& Hobart, 1969) contaminated with a trace of $\beta$-globulin.

The calculation of concentration for sheep IgG and univalent antibody fragments was based on an assumption that $E_{1 \mathrm{~cm}}^{1 \%}$ at $280 \mathrm{~nm}$ is 14.0 , by analogy with other species (Little \& Donahue, 1968).

Purification of anti-(chicken cathepsin D) antibodies on an immunoadsorbent column. Chicken cathepsin $\mathbf{D}$ was coupled to Sepharose 4B exactly as described for staphylococcal nuclease by Omenn, Ontjes \& Anfinsen (1970), and the adsorbent was used in columns maintained at $4^{\circ} \mathrm{C}$. After application of the antiserum, the column was washed with 2 bed vol. of phosphate-buffered saline $\left(0.80 \% \mathrm{NaCl}, 0.02 \% \mathrm{KCl}, 0.02 \% \mathrm{KH}_{2} \mathrm{PO}_{4}\right.$ and $0.12 \%$ $\mathrm{Na}_{2} \mathrm{HPO}_{4}$ ) and then the antibody was eluted with $0.1 \mathrm{M}$ acetic acid in $1 \%(\mathrm{w} / \mathrm{v}) \mathrm{NaCl}$. Immediately after elution, each antibody pool was neutralized with $0.5 \mathrm{M}-\mathrm{Na}_{2} \mathrm{HPO}_{4}$, pH 8.9, concentrated to at least $10 \mathrm{mg} / \mathrm{ml}$ by ultrafiltration and stored at $-20^{\circ} \mathrm{C}$.

Preparation of univalent antibody fragments with papain and pepsin. A papain digest of sheep IgG, made essentially as described by Porter (1959), was separated on Sephadex G-75 into a fraction containing both fragments Fab and Fc, and another containing small peptides, which was discarded. Univalent antibody fragments were prepared from purified antibody by the method of Nisonoff, Wissler, Lipman \& Woernley (1960). The pepsin digestion was at pH5.0 for $17 \mathrm{~h}$, and the pepsin was finally inactivated at $\mathrm{pH}$ 7.7.

Enzyme assays. Cathepsin D was assayed at pH3.2 as described by Barrett (1967, 1970). Activity was also measured at pH5.0 in incubation mixtures $(0.50 \mathrm{ml})$ containing the enzyme sample $(0.10 \mathrm{ml})$, serum or diluent

* Abbreviation: IgG, immunoglobulin G.
$(0.10 \mathrm{ml})$ and buffered haemoglobin solution $[4 \%(\mathrm{w} / \mathrm{v})$ in $0.25 \mathrm{M}$-sodium acetate buffer, pH5.0;0.30 ml]. After $2 \mathrm{~h}$ at $45^{\circ} \mathrm{C}$ the reaction was stopped by addition of $5.0 \mathrm{ml}$ of $3.0 \%(w / v)$ trichloroacetic acid solution. The procedure was then as described for $\mathrm{pH}$ 3.2. The diluent was normal diluting medium consisting of $100 \mu \mathrm{g}$ of bovine serum albumin $/ \mathrm{ml}$ in $0.1 \%(\mathrm{v} / \mathrm{v})$ Triton X-100; buffered diluting medium used in some experiments contained in addition 20 mM-tris-HCl buffer, pH 7.2.

Other enzymes assayed by published techniques were hyaluronidase (Bollet, Bonner \& Nance, 1963), arylsulphatase (Roy, 1958), acid phosphatase (Torriani, 1960), cathepsin B (Greenbaum \& Fruton, 1957), $\beta$-glucuronidase (de Duve, Pressman, Gianetto, Wattiaux \& Appelmans, 1955), $\beta$-glucosidase (Conchie \& Levvy, 1957), $\beta-N$. acetylglucosaminidase (Sellinger, Beaufay, Jacques, Doyen \& de Duve, 1960) and papain, which was determined by a modification of the method of Anson (1939), casein being used as substrate.

Measurement of the inhibitory capacity of antisera. Inhibition was measured at pH5.0 at constant enzyme concentration and various antiserum concentrations. Immediately before use the sera were adjusted to $\mathrm{pH} 5.5$ with $1 \mathrm{M}-\mathrm{H}_{3} \mathrm{PO}_{4}$, a capillary $\mathrm{pH}$ electrode being used. They were then de-gassed under reduced pressure, and the $\mathrm{pH}$ was readjusted to $5.0 \pm 0.1$. Then 4 units of cathepsin D $(10 \mu \mathrm{l})$ were added to each sample of the antiserum $(5-200 \mu \mathrm{l})$ and normal serum was added to make the volume $210 \mu \mathrm{l}$. The mixture was incubated for $15 \mathrm{~min}$ at $37^{\circ} \mathrm{C}$, and then $300 \mu \mathrm{l}$ of haemoglobin solution $(4 \%, w / v)$ in $0.25 \mathrm{M}$-sodium acetate buffer, pH5.0, was added. The mixture was incubated for $2 \mathrm{~h}$ at $45^{\circ} \mathrm{C}$ before the reaction was stopped and the assay completed as described above.

In some experiments inhibition was measured with a constant amount of antiserum $(50 \mu \mathrm{l})$ and increasing amounts of cathepsin D (1-20 units).

Effect of antibody/enzyme ratio on inhibition and precipitation. Antiserum (S467/2) and control normal sheep serum were incubated at $56^{\circ} \mathrm{C}$ for $30 \mathrm{~min}$ to inactivate complement, de-gassed at pH5.5 and adjusted to pH 7.0. The sera were then clarified by centrifuging at $10000 \mathrm{~g}$ for $10 \mathrm{~min}$ and passed through Millipore membrane filters of $0.45 \mu \mathrm{m}$ pore size. Incubation mixtures at six enzyme/ antibody ratios were set up in triplicate as follows. Into each tube was pipetted $2.5 \mathrm{ml}$ (100 units) of chicken cathepsin $\mathrm{D}$ in buffered diluting medium. To each set of tubes was then added, $0,0.16,0.31,0.63,1.25$ or $1.88 \mathrm{ml}$ of antiserum together with sufficient normal serum to make a total of $2.5 \mathrm{ml}$ of serum. The contents of the tubes were mixed and incubated for $15 \mathrm{~min}$ at $37^{\circ} \mathrm{C}$, after which samples were removed for assay of enzymic activity at pH 3.2 $(0.05 \mathrm{ml})$ and $\mathrm{pH} 5.0(0.20 \mathrm{ml})$ by the usual methods except that $30 \mathrm{~min}$ incubation was used at pH3.2. The remainders of the enzyme-antiserum mixtures were allowed to stand at $4^{\circ} \mathrm{C}$ overnight, shaken to resuspend the immunoprecipitates and sampled for assays as before. Duplicate $1.3 \mathrm{ml}$ samples were removed from each mixture to $10 \mathrm{ml}$ tubes and centrifuged at $10000 \mathrm{~g}$ for $10 \mathrm{~min}$. The supernatant fractions from each pair of tubes were combined and sampled for assays as before. In addition, to detect low concentrations of enzyme the supernatants representing the three highest antiserum concentrations were assayed with larger samples $(0.30 \mathrm{ml})$. The precipitates were washed by resuspension in $5.0 \mathrm{ml}$ 
of buffered diluting medium and recentrifugation at $10000 \mathrm{~g}$. One pellet from each pair was then suspended in $1.3 \mathrm{ml}$ of diluting medium with the aid of a handoperated homogenizer, and assays were made as before. The second pellet from each pair was dissolved in $1.3 \mathrm{ml}$ of $0.20 \mathrm{M}$-acetic acid and the $E_{280}$ of the solutions was measured.

Preparation of ${ }^{35} \mathrm{~S}$-labelled chick cartilage. Embryonic cartilage was obtained in the following way. Six-dayincubated eggs were injected with $100 \mu \mathrm{l}$ of sterile $0.9 \%$ $\mathrm{NaCl}$ containing $1 \mu \mathrm{Ci}$ of carrier-free ${ }^{35} \mathrm{SO}_{4}{ }^{2-}$. The injection was made into the sub-blastodermic space by the insertion to $1 \mathrm{~cm}$ of an intradermal syringe needle. The shell was resealed with paraffin wax and the eggs were incubated until day 10-12; at day 10 the long bones contained approx. 20000 c.p.m./mg dry wt.

Cartilage from young animals was obtained from 5-15day-old chickens that had been injected intraperitoneally with $50 \mu \mathrm{Ci}$ of ${ }^{35} \mathrm{SO}_{4}{ }^{2-}$ in sterile $0.9 \% \mathrm{NaCl}$ containing 0.1 mg of carrier $\mathrm{Na}_{2} \mathrm{SO}_{4}$. Older animals (15-30 days) were injected with $100-150 \mu \mathrm{Ci}$.

Removal from cartilage of lysosomal proteolytic enzymes. Embryonic and young fowl long-bone cartilage labelled with ${ }^{35} \mathrm{~S}$ was washed with 100 vol. of $0.1 \%$ Triton $X-100$ in 0.1 M-sodium phosphate buffer, $\mathrm{pH} 7.5$, for $2 \mathrm{~h}$ at $4^{\circ} \mathrm{C}$ with constant agitation. The washing medium was replaced by an equal volume of fresh buffer and the washing continued for $18 \mathrm{~h}$. No acid proteinase activity was then detectable in an homogenate of the washed cartilage.

Action of cathepsin $D$ on washed cartilage. Washed cartilage (20-50 $\mathrm{mg}$ wet wt.) was incubated in a shaking water bath at $37^{\circ} \mathrm{C}$ with $0.2 \mathrm{ml}$ of $0.25 \mathrm{M}$ buffer, $0.3 \mathrm{ml}$ of serum or $0.9 \% \mathrm{NaCl}$ and $100 \mu \mathrm{l}$ of cathepsin D (2-20 units $/ \mathrm{ml}$ ). The buffers used were sodium formate-formic acid, $\mathrm{pH}$ 3.0, sodium acetate-acetic acid, $\mathrm{pH} 4.0$ and 5.0, and $\mathrm{KH}_{2} \mathrm{PO}_{4}-\mathrm{Na}_{2} \mathrm{HPO}_{4}, \mathrm{pH} \mathrm{6.0}$ and 7.0. At the end of the incubation period (usually $2 \mathrm{~h}$, since a linear rate of release was obtained for up to $6 \mathrm{~h}$ ) the incubation medium was removed and the ${ }^{35} \mathrm{~S}$-labelled proteoglycans were precipitated, together with $0.5 \mathrm{mg}$ of chondroitin sulphate as carrier, with $10 \mathrm{vol}$. of ethanol containing $0.027 \%$ of $\mathrm{H}_{2} \mathrm{SO}_{4}$. The precipitate was centrifuged, washed twice with the acid ethanol and dissolved in $0.5 \mathrm{ml}$ of formic acid at $100^{\circ} \mathrm{C}$ for determination of radioactivity in a Packard Tri-Carb liquid-scintillation counter, in the scintillant mixture described by Hall \& Cocking (1965). The tissue was rinsed with $0.9 \% \mathrm{NaCl}$, and digested in $98 \%$ formic acid, at $100^{\circ} \mathrm{C}$ for $1 \mathrm{~h}$. The use of formic acid digests decreased quenching to a minimal level.

Autolysis of cartilage. Whole limb bones were dissected from 10-11-day chicken embryos; with older embryos the cartilaginous ends of the long bones were dissected free from the bony shafts, and with chicks and young fowls slices were cut from the articular surface of the long bones. Rabbit ear cartilage was taken from 6-week-old animals. The cartilage $(20-50 \mathrm{mg}$ wet wt.) was preincubated for $30 \mathrm{~min}$ at $0^{\circ} \mathrm{C}$ with $100 \mu \mathrm{l}$ of $0.5 \mathrm{M}$-sodium acetate buffer, pH 5.0, containing $0.5 \%$ of Triton X-100;0-400 $\mu$ l of serum or antiserum was added and the final volume made up to $500 \mu \mathrm{l}$ with $0.9 \% \mathrm{NaCl}$. The tissue was incubated at $37^{\circ} \mathrm{C}$, usually for $2-3 \mathrm{~h}$, and the released proteoglycans were measured turbidimetrically (Weston, Barrett \& Dingle, 1969), as uronic acid precipitable with cetylpyridinium chloride (Barrett, Sledge \& Dingle, 1966) or radiochemi- cally as described above. Some samples were subjected to diffusion analysis.

Diffusion analysis of cartilage autolysates. Weissman \& Spilberg (1968), using a specially constructed chamber, demonstrated that diffusion through a Millipore membrane filter could be used to follow the digestion of a proteoglycan; this principal was developed to give a routine method for measuring the digestion of cartilage proteoglycan. The method depends on the equilibration of digestion products through a Millipore membrane under controlled conditions of diffusion. Each Swinnex disposable filter holder (Millipore SX00 013) was fitted with a small plastic stopper at each end and the membrane $(0.10,0.22$ or $0.30 \mu \mathrm{m}$ pore size) was placed in position bounded by two ' $O$ ' rings lightly coated with silicone grease. A small glass bead was placed in each side of the chamber, so that on rotation the contents were thoroughly mixed.

At the end of the autolysis period $0.5 \mathrm{ml}$ of cold $1.0 \mathrm{M}$ tris-HCl buffer, pH 8.5, was added to the tissue in its incubation medium and the whole was homogenized. The homogenate was centrifuged at $10000 \mathrm{~g}$ for $5 \mathrm{~min}$ and $200 \mu$ l of the supernatant was placed in the small end of the diffusion chamber. In the larger end of the diffusion chamber was placed $600 \mu \mathrm{l}$ of $0.2 \mathrm{M}$-tris-HCl buffer, $\mathrm{pH} 8.5$, containing $0.02 \mathrm{~m}-\mathrm{EDTA}, 0.1 \%$ of Triton X-100 and $1 \%$ $(v / v)$ of butan-1-ol. Three chambers were normally set up for each tissue sample; a total of 36 chambers could be handled at one time. The chambers were rotated around their long axes at $3 \mathrm{rev} . / \mathrm{min}$ for $24 \mathrm{~h}$ at $4^{\circ} \mathrm{C}$; equilibration occurred within $18 \mathrm{~h}$. Samples $(50 \mu \mathrm{l})$ were taken from both sides of each chamber for scintillation counting and the results are expressed as the percentages of total proteoglycan that was diffusible. The best reproducibility of results was obtained when all the membranes for an experiment were cut from a single large sheet of membrane filter.

\section{RESULTS}

\section{Preparation of antisera and antibody fractions}

Antisera. Cathepsin D purified from human, rabbit and chicken liver was used to immunize rabbits and sheep. It was found that sheep receiving two injections of $3-5 \mathrm{mg}$ of chicken cathepsin D gave potent precipitating antisera. The relative concentrations of precipitating antibodies in the sera were measured by reversed radial immunodiffusion essentially as described by Vaerman et al. (1969) (Plate 1a). Antisera were raised against human and rabbit cathepsin $D$ by injection of straight precipitin lines (Plate 1b). A specific antiserum was raised in a sheep by this method by using $250 \mu \mathrm{g}$ of antigen. All antisera were examined initially by double diffusion against a crude preparation from liver, and those that gave a single precipitin line containing cathepsin D after $24 \mathrm{~h}$ at room temperature were designated 'specific'. All the sheep injected with preparations of chicken cathepsin $D$ homogeneous by analytical isoelectric focusing (Barrett, 1970) produced specific antisera.

Purification of antibodies. Sheep anti-(cathepsin 


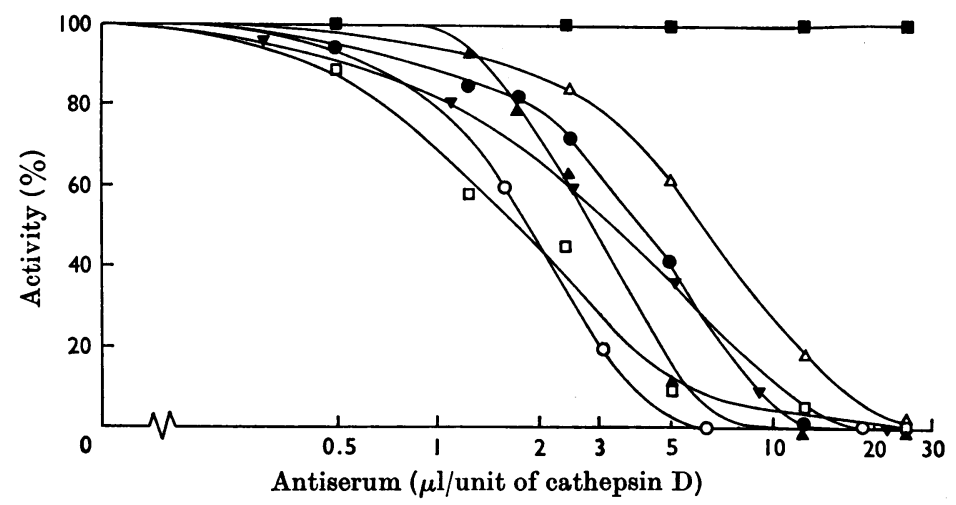

Fig. 1. Inhibition of chicken and rabbit cathepsin D by sheep antisera. Assays for cathepsin D were made on suspensions containing various volumes of antiserum and a fixed volume of enzyme at pH5.0 (see the Methods section). Anti-(chicken cathepsin D) sera: $O, S 467 / 2 ; \triangle, S 570 / 2 ; \square, S 467 / 4 ; \square, S 467 / 4$ passed through immunoadsorbent column; $\Delta, \mathrm{S} 2 / 1 ; \bullet, \mathrm{S} 1 / 1$. Anti-(rabbit cathepsin D) serum: $\nabla, \mathrm{S} 522 / 3$.

D) antibodies were isolated from various sera by the use of an immunoadsorbent column containing chicken cathepsin D covalently linked to Sepharose. Thus, when antiserum S467/4 (14 ml) was passed through a $14 \mathrm{ml}$ bed of the immunoadsorbent containing $14 \mathrm{mg}$ of cathepsin $\mathrm{D}, 70 \mathrm{mg}$ of antibody was absorbed and subsequently eluted. After passage through the column the serum was free of precipitating anti-(cathepsin D) antibodies, as judged by radial immunodiffusion, and showed no capacity to inhibit the enzyme (see below). The eluted antibody fraction was shown to be pure IgG in immunoelectrophoresis developed with two multivalent anti-(sheep serum) sera.

In a subsequent control experiment an equal volume of normal serum was passed through the column, and only a trace of protein was retained to be eluted with dilute acetic acid.

Univalent antibody fragments. To investigate the relationship between immunoinhibition and precipitation, antibody fragments were prepared from sheep anti-(chicken cathepsin D) IgG. Digestion with either papain or pepsin gave non-precipitating univalent fragments. The fragments produced by papain inhibited precipitation of cathepsin D by antiserum in gel diffusion (cf. Kronvall \& Williams, 1969) (Plate 1c).

\section{Inhibition of cathepsin $D$ by antisera}

Comparison of antisera and antibody preparations. The antisera to human, rabbit and chicken cathepsin were effective inhibitors of the enzyme. Fig. 1 shows the results obtained with five sheep anti(chicken cathepsin D) sera, and one that had been depleted of antibody by use of the immunoadsorbent column. The latter serum had no inhibitory action, whereas the other sera all produced complete inhibition of the enzyme, the most effective doing so at about $6 \mu$ l/unit of cathepsin $D$. The inhibition of human cathepsin $D$ by a rabbit antiserum is shown in Fig. 6. Sheep anti-(rabbit cathepsin D) (S522/3) caused complete inhibition of rabbit cathepsin $D$ (Fig. 1).

The amount of precipitating antibodies was not found to give a reliable indication of inhibitory potency. Both IgG1 and IgG2 from an immune serum were inhibitory, but the corresponding proteins from normal sheep sera tested at a high concentration $(300 \mu \mathrm{g} / \mathrm{unit}$ of cathepsin $\mathrm{D})$ were not.

Effect of $\mathrm{pH}$, incubation time and dilution. Inhibition of chicken cathepsin $D$ by antiserum $(\mathrm{S} 467 / 2)$ was measured at $\mathrm{pH} 3.0$ and 4.0 , as well

\section{EXPLANATION OF PLATE I}

Immunodiffusion plates. (a) Radial immunodiffusion plate, to which duplicate samples of a pre-immunization serum (S570/0) and five sheep anti-(chicken cathepsin D) sera were applied, together with doubling dilutions of serum $\$ 467 / 4$ representing $5.0,2.5,1.25,0.62$ and $0.31 \mu l$. (b) Straight precipitin lines for injection formed between troughs filled alternately with non-specific antiserum and suitably diluted purified isoenzyme solution. (c) Papaindigested antibody inhibiting precipitation. $(d)$ Complete identity of human cathepsin $D$ from rheumatoid synovium and liver, shown by using anti-(human cathepsin D) serum (R18/2) fourfold concentrated. (e) Anti-(chicken cathepsin $D \gamma$-isoenzyme) serum ( $\mathbf{5 4 6 7 / 2}$ ) reacting with chicken isoenzymes. $(f)$ Anti-(chicken cathepsin $\mathbf{D} \beta$-isoenzyme) serum (S570/2) reacting with chicken isoenzymes. $(g)$ Anti-(human cathepsin D $\beta$-isoenzyme) serum (R18/1), fourfold concentrated reacting with human isoenzymes. (h) Anti-(rabbit cathepsin D) serum (S522/1) reacting with rabbit isoenzymes. 
(a)

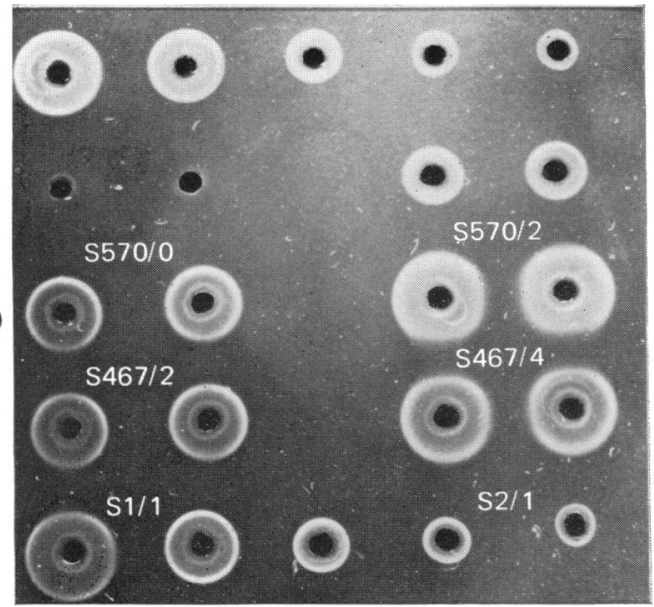

(c)

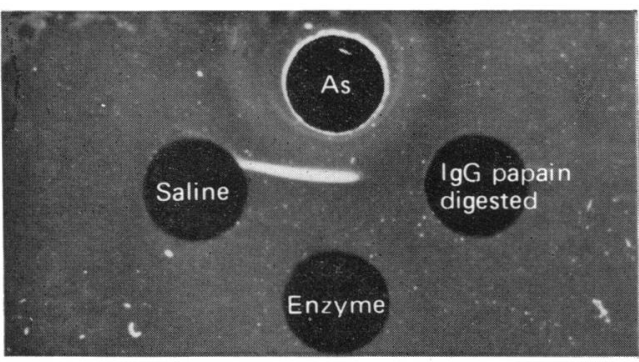

As: anti-(chicken cathepsin D)

(e)

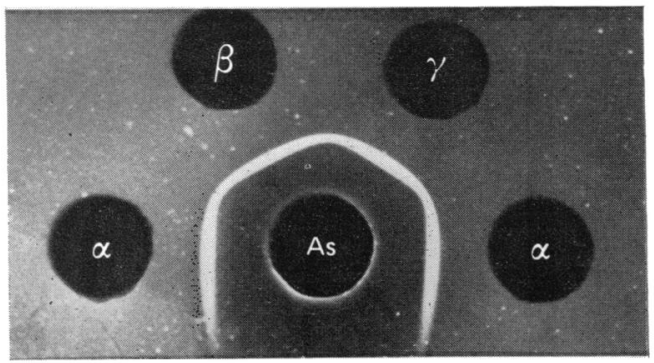

As: anti-(chicken $\gamma$-isoenzyme)

(g)

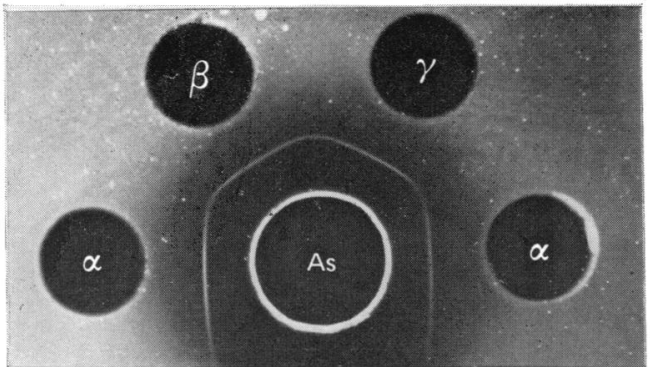

As: anti-(human $\beta$-isoenzyme)

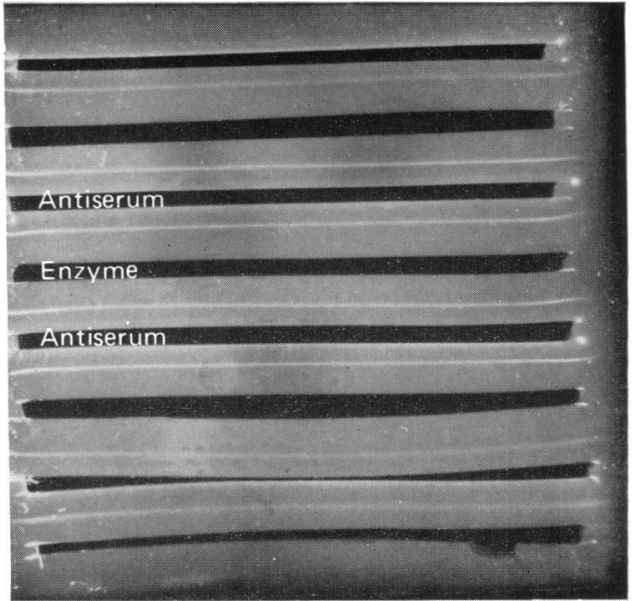

(b)

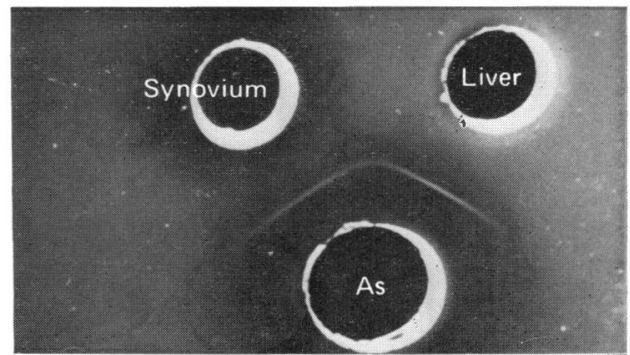

As: anti-(human cathepsin D)

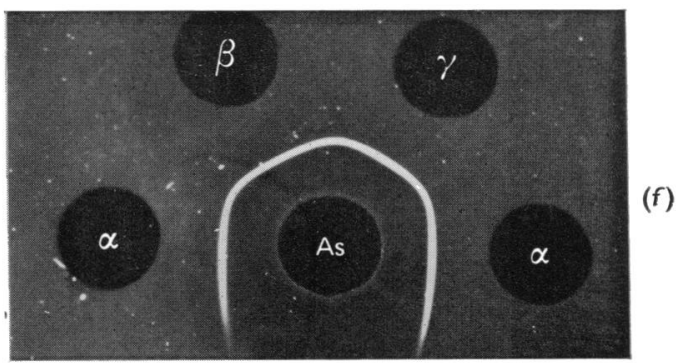

As: anti-(chicken $\beta$-isoenzyme)

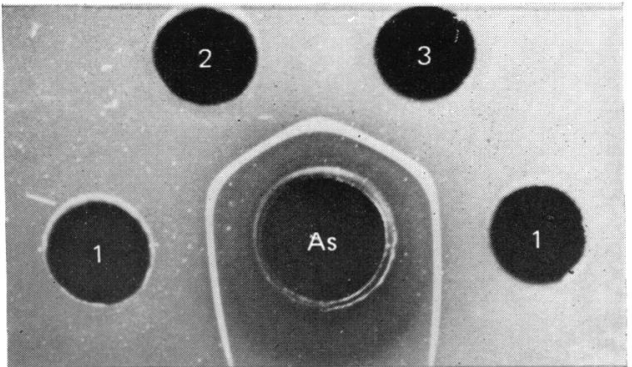

As: anti-(rabbit cathepsin D) 


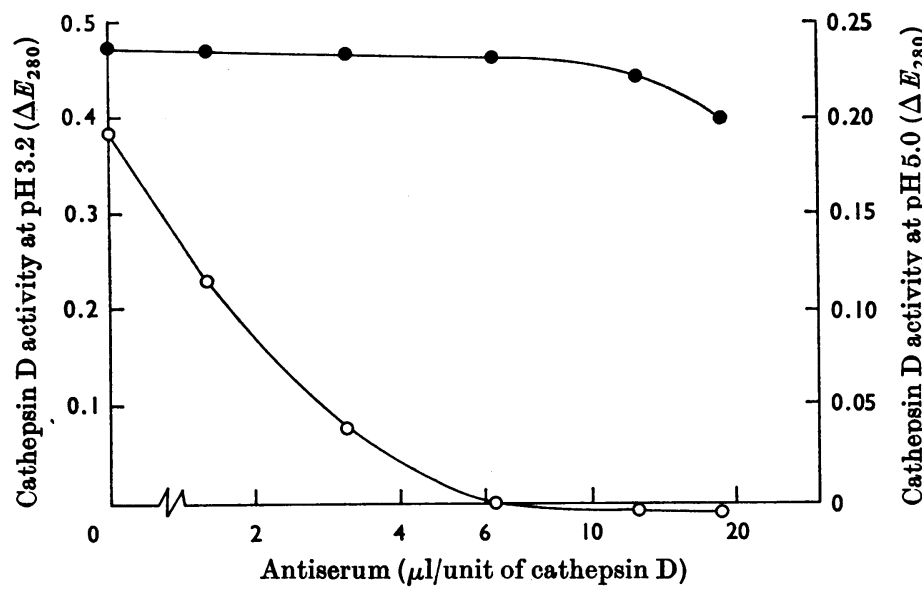

Fig. 2. Effect of antiserum/enzyme ratio on inhibition and precipitation: assays of mixtures before centrifuging. Mixtures of antiserum and cathepsin $D$ at various ratios (0-20 $\mu$ l antiserum/unit of enzyme) were assayed for proteolytic activity at $\mathrm{pH} 3.2(\bullet)$ and $\mathrm{pH} 5.0(0)$ (see the Methods section).

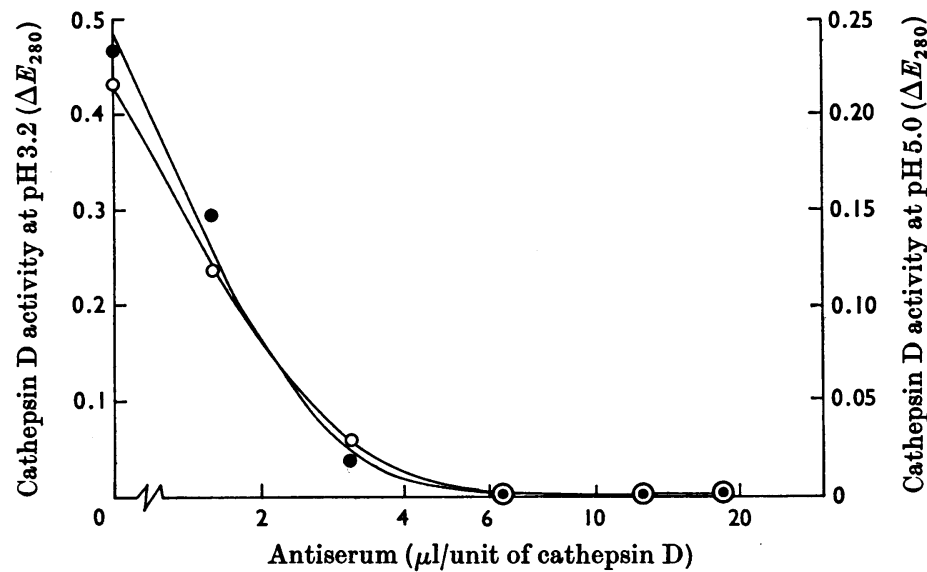

Fig. 3. Effect of antiserum/enzyme ratio on inhibition and precipitation : assays of supernatants. The supernatant fractions obtained after centrifuging the mixtures described in Fig. 2 were assayed for proteolytic activity at $\mathrm{pH} 3.2(\bullet)$ and $\mathrm{pH} 5.0(\mathrm{O})$ (see the Methods section).

as at pH 5.0. At $\mathrm{pH} 3.0$ inhibition was barely detectable, whereas at $\mathrm{pH} 4.0$ it was about $50 \%$ of the pH5.0 value. At pH5.0 a tenfold dilution or prolonged incubation (5.5h) did not affect the degree of inhibition in a single chosen antiserumenzyme mixture (50\% inhibited).

Effect of antibody/enzyme ratio on inhibition and precipitation. A series of mixtures of chicken cathepsin $D$ and antiserum (S467/2) containing 0-18.8 $\mu$ l of antiserum to each unit of enzyme was prepared as described in the Methods section. The first set of assays, made after $15 \mathrm{~min}$ incubation at $37^{\circ} \mathrm{C}$ (Fig. 2), showed an immediate inhibition of activity measurable at $\mathrm{pH} 5.0$, such that $6.3 \mu \mathrm{l}$ of antiserum or above/unit of cathepsin D caused complete inhibition. At $\mathrm{pH} 3.2,9 \%$ inhibition was reached at $18.8 \mu \mathrm{l} /$ unit of enzyme. The assays made after the suspensions had stood overnight were essentially the same as the first set.

The supernatant fractions obtained after removal of the immunoprecipitates by centrifuging showed very similar patterns of activity at both $\mathrm{pH} 3.2$ and pH 5.0 (Fig. 3). From this it seems that there is no significant amount of inhibitor that is nonprecipitating, since this would have produced high activity at $\mathrm{pH} 3$ relative to $\mathrm{pH} 5$, such as was found before removal of the precipitates.

No enzyme activity was detected even in the 


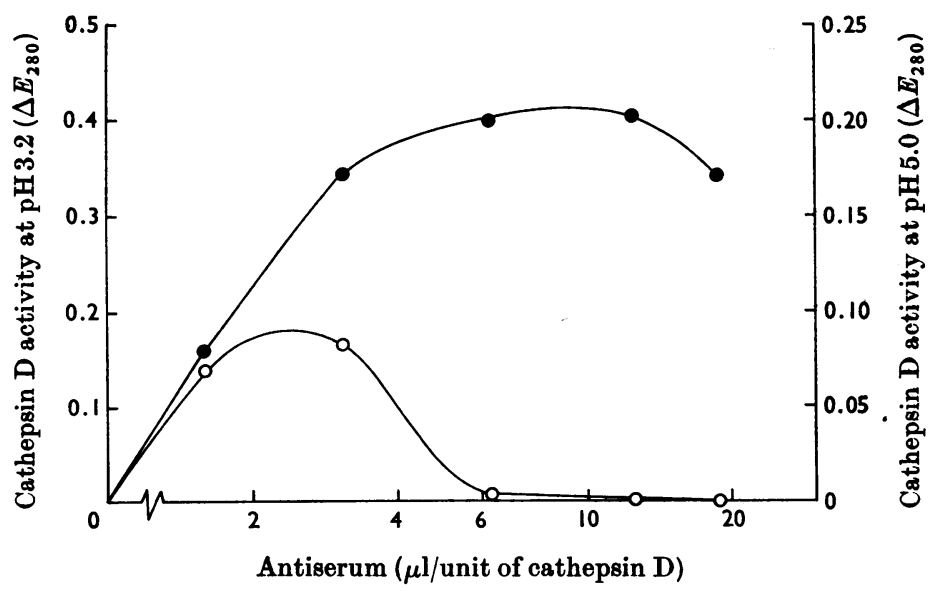

Fig. 4. Effect of antiserum/enzyme ratio on inhibition and precipitation: assays of immunoprecipitates. The precipitates obtained after centrifuging the mixtures described in Fig. 2 were resuspended and assayed for proteolytic activity at pH3.2(๑) and pH 5.0(O) (see the Methods section).

assays made at $\mathrm{pH} 3.2$ with $0.30 \mathrm{ml}$ samples of the supernatants rather than $0.05 \mathrm{ml}$, confirming that there was very complete removal of the enzyme from the soluble phase at $6.3 \mu \mathrm{l}$ of antiserum per unit and above.

The result of assays made with the resuspended immunoprecipitates is recorded in Fig. 4. The values obtained at pH 3.2 show the expected increase in the amount of enzyme precipitated with increasing amounts of antiserum, but the assays at $\mathrm{pH} 5.0$ demonstrate that the enzyme precipitated at $1.6 \mu \mathrm{l}$ of antiserum/unit was largely uninhibited, and activity persisted at $3.1 \mu \mathrm{l} / \mathrm{unit}$, also, but not at $6.3 \mu \mathrm{l} /$ unit.

The finding that precipitates formed at low antiserum/enzyme ratios retained activity raised the question of the stoicheiometry of the enzymeantibody association. From the protein content of the immunoprecipitates (measured as the $E_{280}$ of their solutions in $0.2 \mathrm{M}$-acetic acid), together with assays of cathepsin $\mathrm{D}$ at $\mathrm{pH} 3.2$, it was possible to calculate the molar ratios of antibody to enzyme in the precipitates. In two experiments it was found that precipitates containing 3 or 4 antibody molecules/molecule of enzyme showed only slight inhibition of the enzyme they contained, whereas all activity was lost when 6 or 7 molecules of antibody were bound/enzyme molecule. Precipitates containing about 11 molecules of antibody/molecule of cathepsin D were produced in the presence of a large excess of antibody.

Inhibition by purified antibody and antibody fragments. Purified sheep anti-(chicken cathepsin D) antibody, prepared with an immunoadsorbent column, was an effective inhibitor of the enzyme,

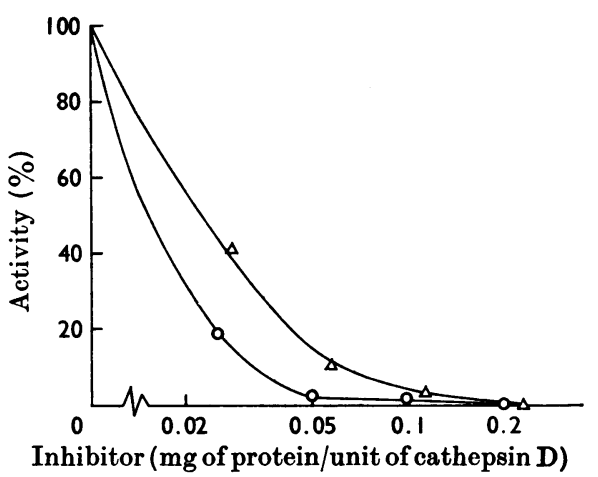

Fig. 5. Inhibition of chicken cathepsin $D$ by purified antibody and by univalent antibody fragments. $O$, Immunoadsorbent-purified antibody; $\Delta$, pepsin digest of immunoadsorbent-purified antibody.

such that $50 \mu \mathrm{g}$ of antibody protein/unit of cathepsin D produced almost complete inhibition (Fig. 5).

The inhibitory capacity of fragments produced by the digestion of IgG from antiserum with papain, or of purified antibodies with pepsin, was determined. It is noteworthy that the fragments produced by pepsin retained most of the inhibitory activity of the original antibody preparation, on a protein basis (Fig. 5). Both preparations, although inhibitory, displayed no appreciable precipitating activity (see above).

Effect of varying the order of mixing of enzyme, antibody and substrate. At a chosen amount of antiserum which gave $80 \%$ inhibition of 6 units of chicken cathepsin $D$, variations were made in the 
order of addition of the three components, enzyme $(150 \mu \mathrm{l})$, sheep anti-(chicken cathepsin D) serum (570/2) $(50 \mu \mathrm{l})$ and substrate (12 mg of haemoglobin in $150 \mu \mathrm{l}$ ). Two components were mixed at $\mathrm{pH} 7.0$, allowed to combine at $37^{\circ} \mathrm{C}$ for $30 \mathrm{~min}$ and then the third was added, followed by $0.25 \mathrm{~m}$-sodium acetate buffer, pH 5.0. The whole mixture was incubated at $45^{\circ} \mathrm{C}$ for $2 \mathrm{~h}$ and the assay for cathepsin $\mathrm{D}$ was completed in the usual way. Inhibition was $80 \pm 2 \%$ for each of the three different ways in which the components were mixed.

\section{Specificity of the antisera}

The initial studies on the specificity of the antisera were made by double diffusion against crude preparations from liver. Further experiments were made on the possible reaction of the antisera with other organs from the same species, with separated isoenzymes of cathepsin $D$ and with other enzymes. The methods used in these experiments were immunodiffusion in gel and inhibition of enzymic activity.

Organ specificity of anti-(chicken cathepsin D) sera. Tissue extracts were prepared from the liver, limbbone cartilage and kidney of five 6-day-old chicks; the specific anti-(chicken cathepsin D) sera used inhibited the cathepsin D of each extract similarly (Table 1), and no difference in inhibition was detected with livers ranging in age from embryonic (14-day) to adult (180-day-old).

Table 1. Organ specificity of anti-(chicken cathepsin D) sera

Determinations with rabbit anti-(chicken cathepsin D) serum (R6/5) were made in duplicate on five animals, and results are expressed as mean percentage inhibitions \pm S.D. Determinations with sheep anti-(chicken cathepsin D) serum S570/2 were made in duplicate on pooled samples of liver from three to five animals at each age, and the results are expressed as mean percentage inhibitions. Tissue extracts in $1 \% \mathrm{NaCl}-0.1 \%$ Triton X-100 $(0.5 \mathrm{ml}$ containing proteolytic activity equivalent to 1 unit of cathepsin D) were incubated with $50 \mu \mathrm{l}$ of antiserum or normal serum for $15 \mathrm{~min}$ at $37^{\circ} \mathrm{C}$. Buffered haemoglobin $(350 \mu \mathrm{l} ; \mathrm{pH} \mathrm{5.0)}$ was added and the assays were completed as described above.

$$
\begin{gathered}
\begin{array}{c}
\text { Chick tissue (age in } \\
\text { days in parentheses) }
\end{array} \\
\overbrace{(\text { antiserum R6/5) }}^{\text {Inhibition (\%) }} \begin{array}{c}
\text { (antiserum } \\
\text { S570/2) }
\end{array}
\end{gathered}
$$

Cartilage (6)

Kidney (6)

Liver (6)

Liver (180)

Liver (8)

Liver (2)

Liver (14 embryonic)
Organ specificity of anti-(human cathepsin D) serum. Crude homogenates of normal human liver and rheumatoid synovia were examined in geldiffusion analysis with the specific anti-(human cathepsin D) serum (R18/1). The precipitin lines that developed fused and gave a reaction of complete identity (Plate 1d); after 4 days' development no spurs were visible in the gel diffusion plate, and the precipitin lines were shown to contain cathepsin D.

Reaction of antisera with separate isoenzymes of cathepsin $D$. One sheep anti-(chicken cathepsin D) serum (S570/2) was prepared by injection of pure $\beta$-isoenzyme and another (S467/2) by injection of pure $\gamma$-isoenzyme. These antisera were examined by double diffusion against the three isoenzymes, $\alpha, \beta$ and $\gamma$ (Plate $1 e$ and $1 f$ ). Each antiserum reacted similarly with each of the three isoenzymes, and the absence of spurs after diffusion had continued for 3 days indicated that the antisera did not contain antibodies restricted to a particular isoenzyme.

The same antisera were tested as inhibitors of the two pure isoenzymes, $\beta$ and $\gamma$. It was found that $30 \mu \mathrm{l}$ of serum $\mathrm{S570/2}$ or $10 \mu \mathrm{l}$ of serum $\mathrm{S467/2}$ completely inhibited 2units of each isoenzyme, whereas 74-84\% inhibition was obtained with 5 units. Thus the specificity of inhibition appeared to be similar to that for precipitation.

A rabbit anti-(human cathepsin D) serum (R18/1) raised by injection of precipitin lines containing only the $\beta$-isoenzyme was examined in doublediffusion analysis against pure human $\alpha$-, $\beta$ - and $\gamma$ isoenzymes (Plate 1g). No spurs appeared during development for 3 days, indicating that the anti(human $\beta$-isoenzyme) serum precipitated equally well with all three isoenzymes. Similar results were obtained with the isoenzymes of rabbit liver (Plate 1h). Another rabbit anti-(human cathepsin D) serum (R15/1), raised by injection of partially purified enzyme, was found to inhibit all three isoenzymes of cathepsin $D$ to approximately the same extent (Fig. 6).

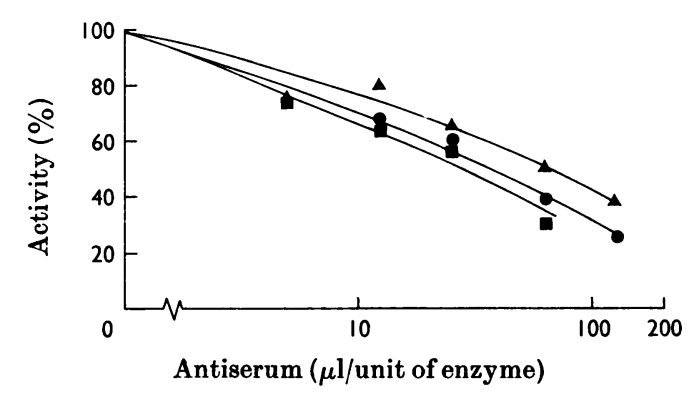

Fig. 6. Inhibition of human $\alpha-, \beta$ - and $\gamma$-isoenzymes by a rabbit antiserum $(\mathrm{Rl5} / 1) . \quad \square, \alpha$-Isoenzyme; $\bullet, \beta$-isoenzyme; $\boldsymbol{\Delta}, \boldsymbol{\gamma}$-isoenzyme. 
Specificity amongst enzymes. An antiserum to chicken liver cathepsin $D$ showed no inhibition of papain, chicken liver acid phosphatase, $\beta$-acetylglucosaminidase, $\beta$-glucuronidase, $\beta$-glucosidase, cathepsin B or hyaluronidase. In immunodiffusion there was no cross-reaction between human plasminogen and human cathepsin $D$.

\section{Immunoinhibition of proteoglycan degradation}

Action of cathepsin $D$ on purified proteinpolysaccharide. The degradation of bovine nasal cartilage protein-polysaccharide in $0.10 \mathrm{~m}$-sodium acetate buffer, pH5.0, containing $0.15 \mathrm{M}$-sodium chloride, was followed by use of viscometers (type UM.4; A. Gallenkamp). The final concentration of substrate was $4.3 \mathrm{mg} / \mathrm{ml}$, and the experiments were made at $37^{\circ} \mathrm{C}$. Under these conditions 5 units of chicken cathepsin $\mathrm{D} / \mathrm{ml}$ caused a rapid fall in viscosity, but the effect was almost completely abolished by the presence of $150 \mu \mathrm{l}$ of rabbit anti-(chicken cathepsin D) serum (R6) (Fig. 7).

Action of cathepsin $D$ on fowl articular cartilage. Pure cathepsin D was found to release labelled proteoglycan from ${ }^{35} \mathrm{~S}$-labelled fowl long bones that had been depleted of endogenous lysosomal enzymes. In experiments in which $50 \mathrm{mg}$ of tissue were incubated in $0.5 \mathrm{ml}$ of buffer containing 2 units of enzyme, half of the labelled proteoglycan was

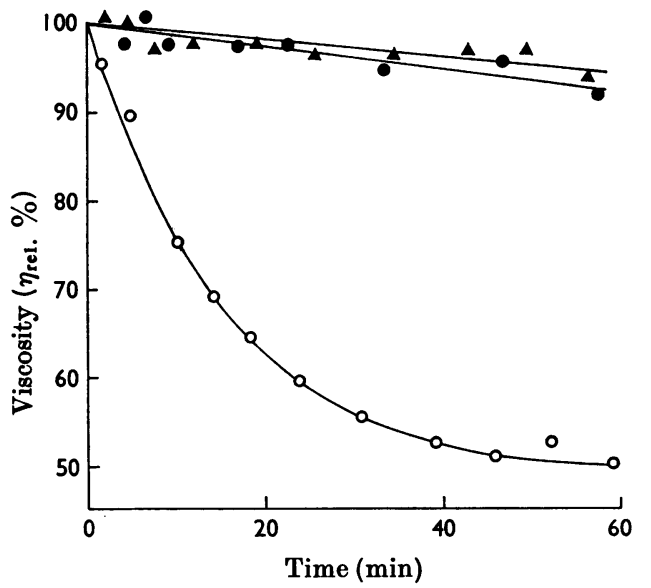

Fig. 7. Action of cathepsin $D$ on cartilage protein-polysaccharide. The viscosity of a $4.3 \mathrm{mg} / \mathrm{ml}$ solution of bovine cartilage protein-polysaccharide was followed at $\mathrm{pH} 5.0$ and $37^{\circ} \mathrm{C}$ in the presence of heat-inactivated cathepsin $\mathrm{D}$ $(\Delta)$, active chicken cathepsin D (5 units $/ \mathrm{ml})$ with $150 \mu \mathrm{l}$ of normal rabbit serum $(O)$ and active cathepsin $D$ ( 5 units/ml) with $150 \mu$ l of rabbit anti-(chicken cathepsin D) serum (R6) (๑). The results are expressed as $\eta_{\text {rel. }} \times 100 /$ $\eta_{\text {rel. }}$ initial. released in $2 \mathrm{~h}$; this concentration of enzyme is comparable with that found in articular cartilage [i.e. 17 units/g at 11 days of age in ovo, 12.5 units/g at 14 days, 8.1 units/g at 17 days and after hatching, 5.9 units/g at 4 days and 5.5 units/g at 18 days of age (these values being the means of triplicate determinations on three animals at each age; J. T. Dingle, unpublished work)]. The pH optimum for the action of pure cathepsin D on cartilage was pH5 (see Fig. 8), unlike that of cathepsin D on haemoglobin, which has been shown to be pH3 (Barrett, 1967).

The action of pure cathepsin $D$ on articular cartilage was inhibited by antiserum; thus at pH5.0 $50 \mu$ decreased the activity by over $90 \%$, complete inhibition being obtained with increased quantities of antiserum. Inhibition occurred in the $\mathrm{pH}$ range 4-8, but as was found with haemoglobin no inhibition occurred at pH 3 (Fig. 8).

\section{Cartilage autolysis}

The four methods used to determine the rate of release of cartilage proteoglycans during autolysis (see the Methods section) gave similar results. The measurement of autolysis as the release of ${ }^{35} \mathrm{~S}$. labelled ethanol-precipitable material from cartilage had the advantage that reproducible results were obtained from experiments with very small amounts

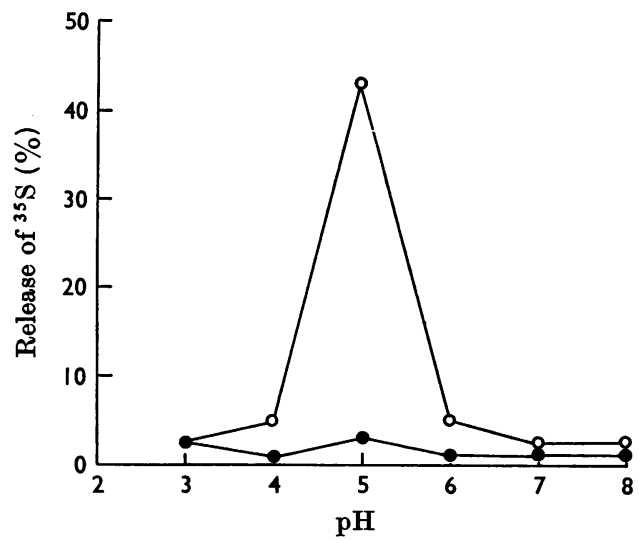

Fig. 8. Action of cathepsin D on cartilage. Articular cartilage $(50 \mathrm{mg}$ ) from 4 -week-old fowl long bones, labelled with ${ }^{35} \mathrm{~S}$ and depleted of lysosomal enzymes (see the Methods section) was incubated with 2 units of chicken cathepsin $\mathrm{D}$ for $2 \mathrm{~h}$ at $37^{\circ} \mathrm{C}$ in a total volume of $0.5 \mathrm{ml}$ containing $50 \mu \mathrm{l}$ of antiserum (S570/2) (๑) or normal serum (0). The results, which are the means of three experiments, each in duplicate, are the ${ }^{35} \mathrm{~S}$ released into the incubation buffer at each $\mathrm{pH}$ (see the Methods section) expressed as percentages of the total ${ }^{35} \mathrm{~S}$. 


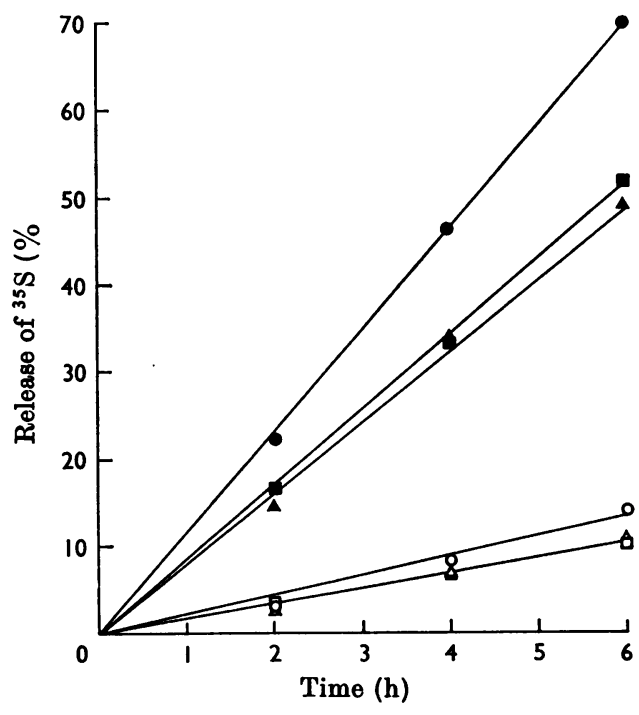

Fig. 9. Autolysis of cartilage. Cartilage (100 mg) labelled with ${ }^{35} \mathrm{~S}$ from chick embryos or young fowls of various ages was autolysed in $0.1 \mathrm{M}$-sodium acetate buffer, pH 5.0, at $37^{\circ} \mathrm{C}$ in the presence of normal sheep serum or antiserum (S570/2) in a total volume of $1.0 \mathrm{ml}$. Samples of the incubation medium were taken at various times for the determination of released ${ }^{35} \mathrm{~S}$. 0,10 -day embryonic cartilage; $O, 10$-day embryonio cartilage plus $50 \mu \mathrm{l}$ of antiserum; $\mathbf{E}, 5$-day-old chick cartilage; $\square, 5$-day-old chick cartilage plus $50 \mu \mathrm{l}$ of antiserum; $\Delta, 21$-day-old fowl cartilage; $\Delta, 21$-day-old fowl cartilage plus $50 \mu \mathrm{l}$ of antiserum.

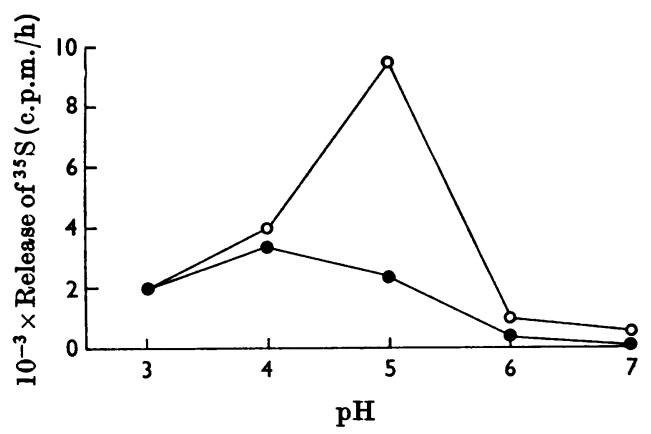

Fig. 10. Effect of $\mathrm{pH}$ on autolysis. The 11-day embryonic chick cartilage $(40 \mathrm{mg})$ labelled with ${ }^{35} \mathrm{~S}$ was allowed to autolyse at $37^{\circ} \mathrm{C}$ at various $\mathrm{pH}$ values. Incubation was for $2 \mathrm{~h}$ at $\mathrm{pH} 5,4 \mathrm{~h}$ at $\mathrm{pH} 3,4$ and 6 , and $6 \mathrm{~h}$ at $\mathrm{pH} \mathrm{7,} \mathrm{in} \mathrm{the}$ presence of $50 \mu \mathrm{l}$ of antiserum (S570/2) (๑) or normal serum (O), in a total volume of $0.5 \mathrm{ml}$. The buffers used were as for the action of cathepsin $D$ on washed cartilage (see the Methods section); the results are expressed as c.p.m. of ${ }^{35} \mathrm{~S}$ released/h and are the mean of duplicate determinations at each $\mathrm{pH}$.

of tissue (2-10 mg dry wt.). Thus in an experiment in which 5-day-old chick cartilage was used the
Table 2. Comparison of the effect of antiserum and pepsin-degraded antibody on the autolysis of 14-day chick cartilage

Autolysis was carried out in the usual manner for $3 \mathrm{~h}$ at $37^{\circ} \mathrm{C}$. The solution of antibody fragments contained $13.5 \mathrm{mg}$ of protein $/ \mathrm{ml}$. The results are the means of three experiments.

\begin{tabular}{ccc}
$\begin{array}{c}\text { Vol. of serum } \\
\text { or antibody } \\
\text { fragments }\end{array}$ & $\begin{array}{c}\text { Pepsin-degraded } \\
\text { antibody } \\
\text { (from S467/2) }\end{array}$ & $\begin{array}{c}\text { Sheep anti- } \\
\text { (chicken cathep- } \\
\text { sin D) antibody }\end{array}$ \\
\cline { 2 - 3 }$(\mu \mathrm{l})$ & & $57 / 2)$ \\
0 & 57 & 57 \\
5 & 42 & 42 \\
10 & 34 & 36 \\
25 & 25 & 9 \\
50 & 22 & 9
\end{tabular}

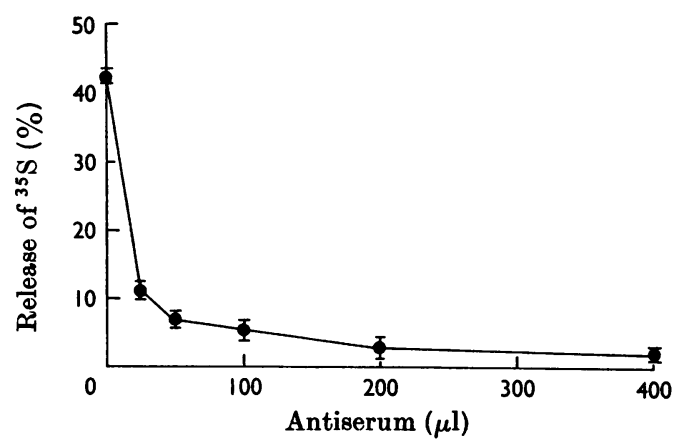

Fig. 11. Immunoinhibition of autolysis of chicken cartilage. The 11-day embryonic cartilage $(100 \mathrm{mg})$ labelled with ${ }^{35} \mathrm{~S}$ was allowed to autolyse for $2.5 \mathrm{~h}$ at $\mathrm{pH} 5$ and $37^{\circ} \mathrm{C}$ in the presence of various quantities of antiserum (S570/2) made up to $400 \mu \mathrm{l}$ with normal serum, in a total volume of $1.0 \mathrm{ml}$. The results, which are the means of three experiments, each done in duplicate, are expressed as the percentages of the total label that were released into the buffer \pm S.E.M.

initial ${ }^{35} \mathrm{~S}$ content of the cartilage ( \pm S.E.M.) was $9740 \pm 330$ (12) c.p.m./mg; after $4 \mathrm{~h}$ autolysis at $\mathrm{pH} 6$ and $37^{\circ} \mathrm{C} 640 \pm 72$ (7) c.p.m./mg was released whereas in the presence of antiserum $290 \pm 32$ (8) c.p.m./mg was released. The rate of release of ${ }^{35} \mathrm{~S}$ was found to be linear with time up to $6 \mathrm{~h}$ in both embryonic and young adult cartilage (Fig. 9). The pH optimum for autolysis was $\mathrm{pH} 5$ for rabbit and chick cartilage (Fig. 10), which is the same as that reported by Lucy, Dingle \& Fell (1961) and very similar to that for the action of pure cathepsin D on washed cartilage (Fig. 8).

Action of antisera on cartilage autolysis. It was possible almost completely to prevent the autolytic breakdown of chicken cartilage by the addition of 


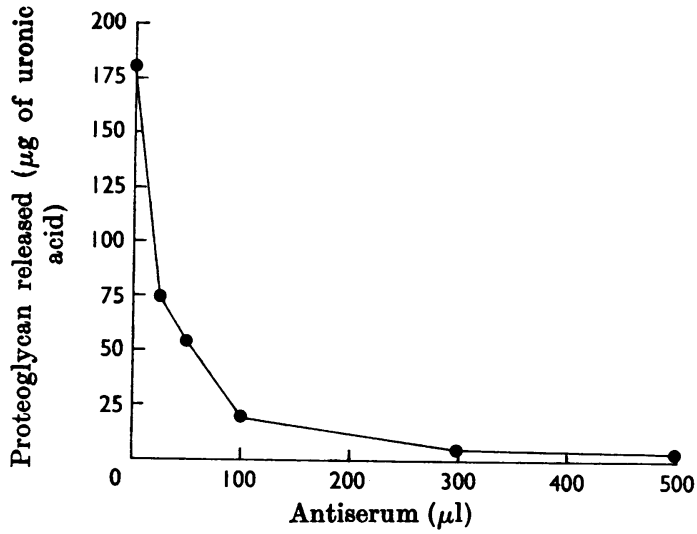

Fig. 12. Immunoinhibition of autolysis of rabbit cartilage. Rabbit ear cartilage $(200 \mathrm{mg})$ was allowed to autolyse at pH5 and at $37^{\circ} \mathrm{C}$ for $2 \mathrm{~h}$. Various quantities of sheep anti-(rabbit cathepsin D) serum (S522/1) were present in a total volume of $2.5 \mathrm{ml}$. The release of proteoglycan fragments was determined as uronic acid precipitable by cetylpyridinium chloride (see the Methods section).

\section{Table 3. Diffusion assay of autolysis}

The 11-day embryonic cartilage was allowed to autolyse at $\mathrm{pH} 5.0$ and $37^{\circ} \mathrm{C}$ for $3 \mathrm{~h}$ in the presence of $100 \mu \mathrm{l}$ of antiserum or normal serum in a final incubation volume of $0.5 \mathrm{ml}$. Other samples of tissue were kept in the incubation medium at $0^{\circ} \mathrm{C}$ for $3 \mathrm{~h}$. At the end of the incubation the tissue was homogenized and set up in diffusion assay with filters of $0.10-0.30 \mu \mathrm{m}$ pore size. The degree of autolysis is expressed as the percentage of diffusible radioactivity and the percentage inhibition is calculated after subtraction of the $0^{\circ} \mathrm{C}$ control values. The results are the means of four estimations \pm s.E.M.

\begin{tabular}{|c|c|c|c|}
\hline & \multicolumn{3}{|c|}{${ }^{35} \mathrm{~S}$ diffusible (\%) } \\
\hline & $\begin{array}{l}0.10 \mu \mathrm{m} \\
\text { filter }\end{array}$ & $\begin{array}{l}0.22 \mu \mathrm{m} \\
\quad \text { filter }\end{array}$ & $\begin{array}{c}0.30 \mu \mathrm{m} \\
\text { filter }\end{array}$ \\
\hline Antiserum & $3.7 \pm 1.1$ & $18.8 \pm 3.1$ & $28.0 \pm 4.0$ \\
\hline $\begin{array}{l}\text { Normal serum } \\
\left(37^{\circ} \mathrm{C}\right)\end{array}$ & $7.8 \pm 1.3$ & $42.2 \pm 3.0$ & $58.7 \pm 4.5$ \\
\hline $\begin{array}{l}\text { Normal serum } \\
\left(0^{\circ} \mathrm{C}\right)\end{array}$ & $2.3 \pm 0.3$ & $9.8 \pm 1.5$ & $12.7 \pm 0.8$ \\
\hline Inhibition (\%) & 74 & 72 & 67 \\
\hline
\end{tabular}

a specific antiserum to cathepsin D (Fig. 11). Inhibition occurred at $\mathrm{pH} 5$, was diminished at $\mathrm{pH} 4$ and absent at pH3 (Fig. 10). The antiserum was effective in inhibiting the autolysis of tissues of various ages (Fig. 9). Non-precipitating antibody fragments obtained by pepsin digestion were also capable of inhibiting autolysis (Table 2).

The release of proteoglycan, determined as precipitable uronic acid during autolysis of ear

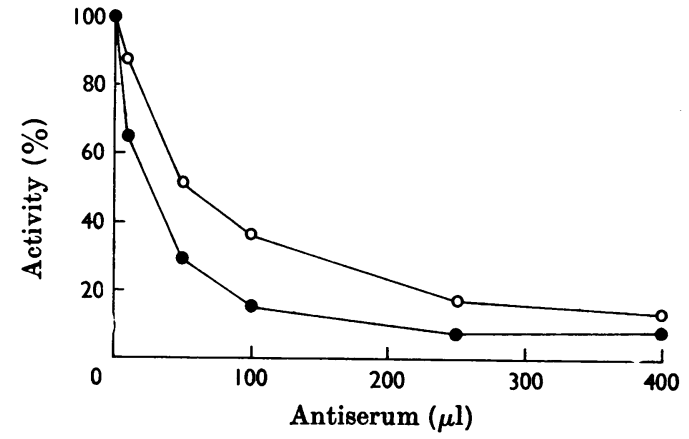

Fig. 13. Diffusion assay of autolysis compared with a conventional method. The 14-day embryonic chick cartilage $(100 \mathrm{mg}$ ) was allowed to autolyse for $3 \mathrm{~h}$ at $\mathrm{pH} 5$ and $37^{\circ} \mathrm{C}$ in the presence of various quantities of antiserum (S570/4). The total volume of serum was always $400 \mu \mathrm{l}$, and the total volume of the mixture was $1.0 \mathrm{ml}$. The release of ${ }^{35} \mathrm{~S}$ into the buffer was measured $(\bullet)$ and diffusion assays were carried out as described in Table 3, with filters of $0.22 \mu \mathrm{m}$ pore size (O). The results obtained by both methods are expressed as percentages of the autolytic release in the presence of normal sheep serum, and are the means of triplicate determinations at each concentration.

cartilage from 6-week-old rabbits for $2 \mathrm{~h}$ at pH 5.0 was over $90 \%$ inhibited by an excess of sheep anti(rabbit cathepsin D) antiserum (Fig. 12). Similar results were obtained in three experiments in which the degree of autolysis was measured turbidimetrically.

Diffusion assay of cartilage autolysis. The results in Table 3 show the percentage of diffusible material present in homogenates of cartilage incubated either at $37^{\circ} \mathrm{C}$ or at $0^{\circ} \mathrm{C}$, filters of three different pore sizes being used. Filters of $0.22 \mu \mathrm{m}$ pore size were used in the experiment in which the diffusion assay was compared with the conventional method (Lucy et al. 1961) for the measurement of autolysis (Fig. 13). Even at high concentrations of antiserum complete inhibition did not occur.

\section{DISCUSSION}

Cathepsin D of chicken, rabbit and man has proved to be a good immunogen in the species we have used, since potent antisera were produced in response to the injection of small amounts of enzyme. All of the precipitating antisera raised against cathepsin $D$ inhibited the enzyme, and several produced complete inhibition in quantities of 6-12 $\mu \mathrm{l}$ /unit of cathepsin D. Incomplete inhibition of cathepsin D and other lysosomal enzymes by an antiserum raised against an extract of lysosomes has been reported by Trouet (1969). In several earlier studies of the immunoinhibition of 
other enzymes (Arnon, 1965; Cinader, 1967) incomplete inhibition even in antibody excess has been reported; this phenomenon may be due to the presence of non-inhibitory antibodies that interfere with the binding of inhibitory ones (Cinader \& Lafferty, 1963; Arnon \& Shapira, 1967), but such antibodies do not seem to be evoked by cathepsin D.

The effect of $\mathrm{pH}$ on the immunoinhibition of cathepsin $D$ in our experiments was predictable from the known pH-dependence of antigen-antibody reactions (Singer \& Campbell, 1955). The dissociation of the immune complex of antibody and cathepsin D at $\mathrm{pH} 3$ was illustrated by the elution of antibody from the immunoadsorbent columns by dilute acetic acid, and by the solubility of the immune precipitates in the same solvent, with the accompanying reappearance of enzymic activity. It was convenient to be able to assay total cathepsin $\mathrm{D}$ at $\mathrm{pH} 3$ and to determine the extent of immunoinhibition in the same preparation at $\mathrm{pH} 5$, and this method was applied to the study of the characteristics of inhibition at various antiserum/enzyme ratios. Enzyme remaining unprecipitated in the antiserum-enzyme mixtures was not inhibited, so that non-precipitating inhibitory antibodies were absent from the antiserum used. Precipitates formed in antigen excess possessed enzymic activity, so aggregation itself does not necessarily result in inhibition and this was further emphasized by the fact that fragment Fab', the non-precipitating univalent product of antibody degradation by pepsin, was inhibitory. These findings are entirely consistent with the results of Marshall \& Cohen (1961) and Cinader \& Lafferty (1963), who used univalent antibody to study the inhibition of carbamoyl phosphate synthetase and ribonuclease respectively. The requirement for a ratio of 6 antibody molecules/molecule of cathepsin $D$ for complete inhibition by the antiserum used is compatible with the hypothesis that loss of activity is due to a steric blockade that is only complete when each molecule is surrounded by many immunoglobulin molecules (cf. Fazekas de St Groth, 1963; Cinader \& Lafferty, 1964; Arnon, 1968).

No effect of dilution or incubation time on the degree of immunoinhibition was detected, indicating that the enzyme-antibody complexes are extremely stable, and that the equilibrium concentrations of free reactants must be very low. Also, degradation of the antibodies by the antigen (cf. Arnon, 1965, with papain), which might have destroyed their inhibitory activity, does not seem to have occurred to a significant extent. Since the haemoglobin/ antibody concentration ratio varied tenfold in the dilution experiment, there was apparently no tendency for the substrate to compete with the inhibitor, at least after the initial reaction. Cinader (1967) stated that antibody is a less effective inhibitor when combining with enzyme in the presence than in the absence of substrate and that the degree of inhibition is commonly affected by the order of mixing of enzyme, antibody and substrate; we could not detect this phenomenon in our experiments.

To be of use in the elucidation of the physiological role of cathepsin $D$ in connective tissue metabolism, it is clear that the antisera must be specific; we therefore supplemented the evidence from immunodiffusion, which demonstrated the specificity of the precipitating activity of the sera, with experiments on the specificity of inhibition. As expected from the known specificity of immunological reactions, the antisera to chicken cathepsin $D$ did not inhibit a number of other enzymes that might contribute to connective-tissue turnover. It has been shown that antisera to human and rabbit cathepsin D, raised in rabbit and sheep respectively, do not react with cathepsin $D$ from a number of other mammals, whereas antisera to chicken cathepsin $D$ raised in rabbits reacted with cathepsin $D$ from a variety of different species of bird (P. D. Weston, unpublished work).

Although we are primarily concerned with the function of cathepsin $D$ in cartilage, this was not a practicable source of the enzyme and it was necessary to raise antisera against cathepsin $D$ prepared from liver. It was possible that antisera raised against the liver enzyme might fail to react with that of cartilage, for several enzymes are known to occur in organ-specific forms that are immunologically distinct (Sussman, Small \& Cotlove, 1968; Henion \& Sutherland, 1957; Sherwin, Karpati \& Bulcke, 1969). However, Weston (1969) reported that cathepsin D of chicken liver, heart, kidney, spleen, testis, brain and embryonic bone rudiments are indistinguishable in immunoprecipitation; we have now shown similar tissue non-specific immunoinhibition of acid proteinase activity of extracts made from liver, cartilage or kidney of 6-day-old chicks. Also, cathepsin D from human rheumatoid synovium was indistinguishable in immunodiffusion from the human liver enzyme.

The finding that the major isoenzymes of chicken liver cathepsin D are immunologically identical, both in precipitation and in inhibition, is not unexpected, since the molecules probably differ in only a few amino acid residues (Barrett, 1971).

The work reported in the first part of this paper formed the basis for an immunoenzymic investigation of the role of cathepsin $D$ in connective-tissue metabolism. Thus in the second part of the work it has proved possible to inhibit the action of cathepsin D on purified bovine nasal protein-polysaccharide and on cartilage that had been depleted of its own proteinases. More important was the finding that the degradation of young chicken and rabbit 
cartilage by endogenous enzymes could be inhibited by up to $90 \%$ by specific antisera. The assay of autolysis by measurement of the material released into the incubation fluid, though simple and reliable, suffers from two disadvantages. It seems likely from the work of Morrison (1970) that the proteoglycans degraded during autolysis are still of very high molecular weight, so that the rate of diffusion of these molecules will depend on the composition of the matrix, which itself alters during autolysis. It is also difficult accurately to determine the small amount of diffusible proteoglycan present initially without activation of the lysosomal system. To overcome these difficulties we developed a diffusion assay in which filters of controlled pore size were used; results obtained with this method confirmed the degree of inhibition by anti-(cathepsin D) sera.

It is concluded that cathepsin $D$ is the enzyme mainly responsible for the breakdown of proteoglycans during the autolysis of chicken and rabbit cartilage; a major role of cathepsin B proposed earlier (Ali, 1964) now seems to be excluded.

It is also becoming clear that cathepsin D plays an important part in the resorption of living cartilage. Thus in preliminary experiments $(H . B$. Fell and J. T. Dingle, unpublished work) the release of ${ }^{35} \mathrm{~S}$-labelled material from limb-bone rudiments treated with vitamin $\mathbf{A}$ in organ culture was decreased by $35-50 \%$ in the presence of anti-(chicken cathepsin D) sera. These results have been extended and confirmed (R. M. Hembry \& J. T. Dingle, unpublished work). Rudiments grown in the presence of antisera retained relatively more polysaccharide than controls and showed a higher ratio of dry weight to total nucleic acids.

We gratefully acknowledge the help of Professor T. R. R. Mann, F.R.S., and Dr H. M. Dott of the Agricultural Research Council Unit of Reproductive Physiology and Biochemistry, University of Cambridge, and Mr J. C. Heath of the Strangeways Research Laboratory, who made the sheep available. We acknowledge the skilled technical assistance of Mrs M. A. Brown, Miss B. Bunting, Miss M. Francken and Mrs D. Shelford. We thank Dr P. Wolf, University of Birmingham, who investigated the possible cross-reaction between human plasminogen and cathepsin D. Human synovial tissue was kindly made available by the orthopaedic surgeons of Addenbrooke's Hospital, Cambridge. The work was financed by grants from the Wellcome Foundation and the Arthritis and Rheumatism Council. J.T.D. is a member of the staff of the Medical Research Council.

\section{REFERENCES}

Ali, S. Y. (1964). Biochem. J. 93, 611.

Ali, S. Y., Evans, L., Stainthorpe, E. \& Lack, C. H. (1967).

Biochem. J. 105, 549.

Anson, M. L. (1939). J. gen. Physiol. 22, 79.

Arnon, R. (1965). Immunochemistry, 2, 107.
Arnon, R. (1968). Eur. J. Biochem. 5, 583.

Arnon, R. \& Shapira, E. (1967). Biochemistry, Easton, 6, 3942.

Barrett, A. J. (1967). Biochem. J. 104, 601.

Barrett, A. J. (1968). In Comprehensive Biochemistry, vol. 26B, p. 425. Ed. by Florkin, M. \& Stotz, E. H. Amsterdam : Elsevier Publishing Co.

Barrett, A. J. (1969). Biochem. J. 115, 36 P.

Barrett, A. J. (1970). Biochem. J. 117, 601.

Barrett, A. J. (1971). In Tissue Proteinases, p. 109. Ed. by Barrett, A. J. \& Dingle, J. T. Amsterdam: NorthHolland Publishing Co. (in the Press).

Barrett, A. J., Sledge, C. B. \& Dingle, J. T. (1966). Nature, Lond., 211, 83.

Bollett, A. J., Bonner, W. M. \& Nance, J. L. (1963). J. biol. Chem. 238, 3522.

Bollett, A. J., Handy, J. R. \& Sturgill, B. C. (1963). J. clin. Invest. 42, 853.

Cinader, B. (1967). In Antibodies to Biologically Active Molecules, Proc. FEBS 2nd Meet., Warsaw, vol. 1, p. 85.

Cinader, B. \& Lafferty, K. J. (1963). Ann. N.Y. Acad. Sci. 103, 653.

Cinader, B. \& Lafferty, K. J. (1964). Immunology, 7, 342.

Conchie, J. \& Levvy, G. A. (1957). Biochem. J. 65, 389.

de Duve, C., Pressman, B. C., Gianetto, R., Wattiaux, R. \& Appelmans, F. (1955). Biochem. J. 60, 604.

Dingle, J. T. (1962). Proc. R. Soc. Med. 55, 109.

Dingle, J. T. (1968). In Rheumatic Diseases, p. 80. Ed. by Duthie, J. J. R. \& Alexander, W. R. M. Edinburgh University Press.

Dingle, J. T. (1969). In Lysosomes in Biology and Pathology, vol. 2, p. 421. Ed. by Dingle, J. T. \& Fell, H: B. Amsterdam: North-Holland Publishing Co.

Fazekas de St Groth, S. (1963). Ann. N.Y. Acad. Sci. 103, 674.

Feinstein, A. \& Hobart, M. J. (1969). Nature, Lond., 223, 950.

Fisher, D., Higham, M., Kent, P. W. \& Pritchard, P. (1966). Biochem. J. 98, 46 P.

Fisher, D., Whitehouse, M. W. \& Kent, P. W. (1967). Nature, Lond., 213, 204.

Gerber, B. R., Franklin, F. C. \& Schubert, M. (1960). J. biol. Chem. 235, 2870.

Greenbaum, L. M. \& Fruton, J. S. (1957). J. biol. Chem. 226, 173.

Hall, T. C. \& Cocking, E. C. (1965). Biochem. J. 96, 626.

Hamerman, D. \& Barland, P. (1966). Bull. rheum. Dis. $16,396$.

Henion, W. F. \& Sutherland, E. W. (1957). J. biol. Chem. $224,477$.

Kronvall, G. \& Williams, R. C. (1969). J. Immun. 103, 828.

Little, J. R. \& Donahue, H. (1968). In Methods in Immunology and Immunochemistry, vol. 2, p. 346. Ed. by Williams, C. A. \& Chase, M. W. New York: Academic Press Inc.

Lucy, J. A., Dingle, J. T. \& Fell, H. B. (1961). Biochem. J. 79, 500.

Marshall, M. \& Cohen, P. P. (1961). J. biol. Chem. 236, 718.

Morrison, R. I. G. (1970). In Chemistry and Molecular Biology of the Intercellular Matrix, p. 1683. Ed. by Balazs, E. A. New York: Academic Press Inc. 
Nisonoff, A., Wissler, F. C., Lipman, L. N. \& Woernley, D. L. (1960). Archs Biochem. Biophys. 89, 230.

Omenn, G. S., Ontjes, D. A. \& Anfinsen, C. B. (1970). Nature, Lond., 225, 189.

Page-Thomas, D. P. (1969). In Lysosomes in Biology and Pathology, vol. 2, p. 87. Ed. by Dingle, J. T. \& Fell, H. B. Amsterdam: North-Holland Publishing Co.

Porter, R. R. (1959). Biochem. J. 73, 119.

Roy, A. B. (1958). Biochem. J. 68, 519.

Sellinger, O. Z., Beaufay, H., Jacques, P., Doyen, A. \& de Duve, C. (1960). Biochem. J. 74, 450.

Sherwin, A. L., Karpati, G. \& Bulcke, J. A. (1969). Proc. natn. Acad. Sci. U.S.A. 64, 171.

Singer, S. J. \& Campbell, D. H. (1955). J. Am. chem. Soc. 77, 3504.
Sussman, H. H., Small, P. A. \& Cotlove, E. (1968). J. biol. Chem. 243, 160.

Torriani, A. M. (1960). Biochim. biophys. Acta, 38, 460.

Trouet, A. (1969). Caractéristiques et Propriétés Antigenique des Lysosomes du Foie. Louvain: Vander.

Vaerman, J. P., Lebacq-Verheyden, A. M., Scolari, L. \& Heremans, J. F. (1969). Immunochemistry, 6, 287.

Weissman, G. \& Spilberg, I. (1968). Arthr. Rheum. 11, 162.

Weston, P. D. (1969). Immunology, 17, 421.

Weston, P. D., Barrett, A. J. \& Dingle, J. T. (1969). Nature, Lond., 222, 285.

Woessner, J. F. (1967). Fedn Proc. Fedn Am. Socs exp. Biol. 26, 607. 